Article

\title{
The "Dobry Czas Na Biznes" ("Good Time for Business") Program as a Form of Support for Self-Employment in Poland. A Case Study of the Sub-Regions of the Małopolskie Province
}

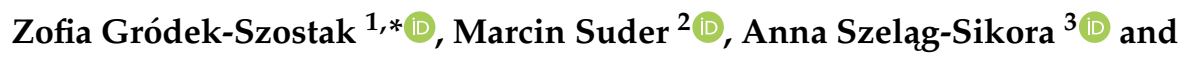 \\ Luis Ochoa Siguencia ${ }^{4}$ (i) \\ 1 Department of Economics and Enterprise Organization, Cracow University of Economics, \\ 31-510 Kraków, Poland \\ 2 Department of Applications of Mathematics in Economics, Faculty of Management, \\ AGH University of Science and Technology, 30-067 Kraków, Poland; msuder@agh.edu.pl \\ 3 Faculty of Production and Power Engineering, University of Agriculture in Krakow, 30-149 Kraków, Poland; \\ Anna.Szelag-Sikora@ur.krakow.pl \\ 4 Department of Sport and Tourism Management, Academy of Physical Education in Katowice, \\ 40-065 Katowice, Poland; 1.ochoa@awf.katowice.pl \\ * Correspondence: grodekz@uek.krakow.pl
}

Received: 15 September 2020; Accepted: 17 November 2020; Published: 20 November 2020

\begin{abstract}
The main goal of public intervention is to amend market imperfections. However, public agencies may also have other goals in supporting entrepreneurship and promotion of self-employment. The aim of the paper is to analyze the impact of the funding granted by the Małopolska Agency for Regional Development (Małopolska Agencja Rozwoju Regionalnego SA, MARR S.A.) dedicated to beneficiaries from the Tarnow subregion and the Krakow Metropolitan Area. The research goals were defined as follows: (1) To verify if the basic assumptions of the program are correct and to demonstrate that it is an important element motivating the professionally inactive to take up employment as sole entrepreneur. (2) To verify if the program participant structure (both applicants and beneficiaries), with subdivision into place of residence, gender, age and the labor market status, is correct. (3) To verify if the abovementioned variables (gender, age, place of residence) significantly differentiate the applicants' chance of obtaining a grant. The results are of key importance and should be used in formulating assumptions, regulations and guidelines for subsequent program editions. Due to the demonstrated diversity of the target group in the respective regions, it should be decided whether to differentiate the criteria for participation in the project depending on the region.
\end{abstract}

Keywords: management; entrepreneurship; public support; self-employment; economy; efficiency

\section{Introduction}

Entrepreneurship plays an important role in the development of the economy and society [1]. Entrepreneurs-to-be are motivated by, e.g., the need for self-fulfillment and personal satisfaction [2-4], accumulating wealth [5], increasing one's social status, the need for autonomy [6,7], the need to find a work-life balance [8], to gain invaluable experience, to realize one's own potential, and job satisfaction [9]. However, among many motives for making the decision about starting a business, the most important are economic factors $[10,11]$. Numerous studies show that the variety of motivations depends on the entrepreneurs' background [12] and the wealth of the country in which the potential entrepreneur resides [13]. However, despite the strong motivation to establish a business, entrepreneurs face a number of difficulties, such as lack of work experience and financing [14]. 
Research shows [15-17] that the capital market is the driving force of economic growth. Adequate financing is the key determinant of business success, especially in the start-up phase. According to research, the greatest sources of capital are: the entrepreneurs' own funds [18], loans from family members [19], own funds, including savings [20], and public funding [21-23].

The main justification for public intervention is to amend market imperfections. However, public agencies may also have other goals in supporting entrepreneurship and promotion of self-employment. The aim of the paper is to analyze the impact of the funding granted by the Małopolska Agency for Regional Development (Małopolska Agencja Rozwoju Regionalnego SA, MARR S.A.) to beneficiaries from the Tarnow subregion (TS) and the Krakow Metropolitan Area (KMA).

The research goals were defined as follows:

1. To present the basic assumptions of the program and to demonstrate that it is an important element motivating the professionally inactive to take up employment as sole entrepreneur.

2. To present and discuss the program participant structure (both applicants and beneficiaries), with subdivision into place of residence, gender, age and the labor market status.

Verifying whether the above-mentioned variables (gender, age, place of residence) significantly differentiate the applicants' chance of obtaining a grant.

\section{Literature Review}

Business finance literature emphasizes the challenges of obtaining external funding. This is due to uncertainty about whether projects aimed at initiating new business would produce useful results or ultimately be financially successful. Moreover, information asymmetries between entrepreneurs and capital providers are particularly high in knowledge-intensive sectors [24]. The complexity and novelty of products and services often mean that the founders have much more insight into technology than the potential financier. Moreover, the founders are usually reluctant to share proprietary information for fear that it will reach followers and larger competitors [25-27]. Unevenly distributed information presents external equity providers with two problems. The first is covert information, as the providers are unable to fully assess the quality of a potential investment ex-ante. The second is the problem of covert action after the founder receives capital.

Direct, grant-based financial support to promote self-employment has become a popular policy instrument to reduce the financial constraints that hinder creating radical innovation, employment and economic growth. While there are several comprehensive literature reviews on the impact of subsidies on innovation activities in well-established enterprises [28-31], there is less insight regarding public support for young high-tech enterprises. Table 1 presents an overview of research on the impact of subsidies on the development of entrepreneurship. The literature review presented in the table is to organize the information presented. The review was conducted using sciencedirect.com and researchgate.net, with the phrase "public subsidies for setting up a business" as the search term.

Table 1. Overview of research on the impact of subsidies on the development of entrepreneurship.

\begin{tabular}{ccl}
\hline No. & Author(s) & \multicolumn{1}{c}{ Research Results } \\
\hline 1. & Lerner [32] and Howell [33] & $\begin{array}{l}\text { found that Small Business Innovation Research (SBIR) grant } \\
\text { recipients excel in attracting further funding and outperform } \\
\text { others in terms of innovation success }\end{array}$ \\
\hline 2. & Söderblom et al. [34] & $\begin{array}{l}\text { found that the Swedish government program helps to attract } \\
\text { human capital. They also concluded that the subsidies } \\
\text { facilitate access to further capital investment, mainly through } \\
\text { business angels, impact employment and increase sales. }\end{array}$ \\
\hline 3. & $\begin{array}{c}\text { Colombo et al. [35], Grilli and } \\
\text { Murtinu [36] and } \\
\text { Colombo et al. [37] }\end{array}$ & $\begin{array}{l}\text { prove to Italian new technology companies that subsidies } \\
\text { positively impact R\&D spending and employment. }\end{array}$ \\
\hline
\end{tabular}


Table 1. Cont.

\begin{tabular}{|c|c|c|}
\hline No. & Author(s) & Research Results \\
\hline 4. & Cantner and Kösters [38] & $\begin{array}{l}\text { argue that subsidized newly established businesses obtain } \\
2.8 \text { more patents than the non-subsidized firms and have } 66 \% \\
\text { higher employment growth. }\end{array}$ \\
\hline 5. & Conti [39] & $\begin{array}{l}\text { found that the assumptions of an Israeli support program have } \\
\text { affected its effectiveness. The restrictions on the transfer of } \\
\text { know-how from a certain geographical region have } \\
\text { undermined the value of participation in the program. } \\
\text { However, when these restrictions were removed, } \\
\text { the program's benefits for start-ups in terms of survival, } \\
\text { attracting external investors and level of innovation, increased. }\end{array}$ \\
\hline 6. & Almeida, Galasso [40] & $\begin{array}{l}\text { investigate the impact of financial and technical assistance for } \\
\text { welfare beneficiaries on their way to self-employment in } \\
\text { Argentina. They observed a period of } 12 \text { months in 2004/2005 } \\
\text { and found an increase in total working hours but no } \\
\text { significant income effects due to the program. However, } \\
\text { for young and highly educated individuals they were able to } \\
\text { identify positive income effects. }\end{array}$ \\
\hline 7. & Rodriguez-Planas [41] & $\begin{array}{l}\text { studied a Romanian start-up program, in which the } \\
\text { participants received professional assistance in the form of } \\
\text { consulting or short-term entrepreneurship training. }\end{array}$ \\
\hline 8. & O'Leary [42] & $\begin{array}{l}\text { considered self-employment programs in Poland and } \\
\text { Hungary. The author reported their significant and positive } \\
\text { effects on employment in both countries. }\end{array}$ \\
\hline 9. & Carling and Gustafson [43] & $\begin{array}{l}\text { present a comparative analysis between employment and } \\
\text { self-employment subsidies for the unemployed in Sweden. } \\
\text { They conclude that subsidized workers are more likely to } \\
\text { return to unemployment than those receiving } \\
\text { self-employment grants. Therefore, they concluded that } \\
\text { subsidies for self-employment are more effective in } \\
\text { decreasing unemployment. }\end{array}$ \\
\hline 10. & Cueto and Mato [44] & $\begin{array}{l}\text { analyzed the success of self-employment subsidies for } \\
\text { individual Spanish districts and found that market survival } \\
\text { rates were approx. } 93 \% \text { after two years and } 76 \% \text { after five. }\end{array}$ \\
\hline 11. & Perry [45] & $\begin{array}{l}\text { assessed grants for corporate subsidies, an integrated program } \\
\text { providing business skills training and financial assistance. } \\
\text { The author's results indicate a reduced unemployment } \\
\text { registration time for participants. }\end{array}$ \\
\hline 12. & Meager et.al. [46] & $\begin{array}{l}\text { evaluate business start-up subsidies by the Prince Trust to } \\
\text { young people in the UK. The authors conclude that } \\
\text { participating in the programme does not have any significant } \\
\text { impact on subsequent employment or earning chances. } \\
\text { Nonetheless, descriptively, they found a fraction of } 69.1 \% \text { in } \\
\text { self-employment among participants after } 18 \text { months. }\end{array}$ \\
\hline 13. & Kelly et.al. [47] & $\begin{array}{l}\text { consider an allowance paid up to } 52 \text { weeks as well as } \\
\text { trainingand counseling in Australia. The authors found a } \\
\text { survival rate of } 56.2 \% \text { in self-employment after three years } \\
\text { following start-up. }\end{array}$ \\
\hline
\end{tabular}

Source: Own study.

As Kubera [48] points out, in Poland, the role of public funding as a tool for achieving immediate political goals gradually decreases, and its role as the stimulant for socio-economic development increases. Regardless of the purpose of the grants, they have always been tempting for many future entrepreneurs, to be used in accordance with the defined competition criteria. Public intervention, 
which is a part of entrepreneurship-oriented activities, has evolved over time. This stems both from the level of the available financial resources and the socio-economic changes $[49,50]$. The experience of other economies does not unambiguously confirm the positive impact of microfinancing on the development of entrepreneurship [51].

Many countries have observed a significant increase in the number of newly established businesses, especially micro-, small and medium-sized enterprises (SMEs) [52]. EU member states stimulate entrepreneurship by offering numerous incentives and sources of external financing for new entrepreneurs, usually non-refundable, public support [53].

\section{Materials and Methods}

\subsection{The Socio-Economic Potential of the Studied Subregions}

According to Polish Labour Force Survey (LFS), conducted quarterly since May 1992 according to the International Labour Organization (ILO) methodology on a national sample of households [49,54], in 2014, 44\% of people in the working age in Poland were economically inactive. According to the Central Statistical Office [50,55], the share of the economically inactive by age groups was as follows: $25-34$ years $(14 \%), 35-44$ years $(12 \%), 45-54$ years $(18 \%), 55+$ years $(75 \%)$. The reasons for their professional passivity were: learning and enhancing qualifications $26.9 \%$; disease/disability $24.5 \%$; family responsibilities $23.7 \%$; retirement $12.3 \%$. The resources of the unemployed are supplemented by the data of the County Labor Offices. At the end of the third quarter of 2015 [55], there were 115,600 unemployed (8.2\%) in the Małopolska region. In the case of TS, there were 20,300 professionally inactive people, including 12,500 people aged $30+$. On the county level the unemployment rate was approx. 10-11\% (Brzesko, Tarnow counties), up to 15.4\% (Dabrowski county), $8.2 \%$ for the City of Tarnow (4700), and in the remaining part of TS, up to 7800. The 50+ professional activity rate is over $34 \%$. The average age of the unemployed is growing, unemployment for people aged $50+$ is increasing, but also the professional activity of the 50+ inactive is increasing dynamically. Every other person aged 50-64 is employed, as well as $43.8 \%$ of those aged 55-64. This is the result of an aging population. The cause of professional inactivity (apart from retirement benefits) was learning/enhancing qualifications/illness/disability. Following a registration, they stay unemployed longer than others (e.g., due to low level of education). These people are often unfamiliar with new technologies or lose their previously acquired qualifications due to the long period of unemployment. The forms of learning for this group are inadequate. The existing forms are not adapted to their needs and predispositions. Information on training is also not widely available, with a deficit in the supply of educational services being visible in smaller towns and in rural areas. On the other hand, representatives of the 50+ age group use modern communication technologies to a lesser extent, being the most at risk from digital exclusion; currently they are only $18 \%$ of Polish internet users $[51,56,57]$.

The long-term unemployed constituted over $60 \%$ of the registered unemployed, for the ST area it was 7800 aged $30+$. Long-term unemployment is a very difficult and complex social problem. It causes the loss of up-to-date professional know-how, knowledge of the market and professional realities, and is combined with a decreased motivation, reluctance/lack of interest in change. The ability to maintain a permanent job is decreasing, replaced by obtaining means on a day-to-day basis.

In the Małopolskie province, people with disabilities constitute $11.8 \%$ of the population [52,57]. According to the 2011 National Census [53,58], the number is 51,000 in the counties of TS. Disability is more common in large urban centers. In terms of education, a lower level of education can be identified among people with disabilities. The employment rate in this group is $18 \%$. People with disabilities belong to the groups of unemployed people that are least likely to take up work (1-2 people/month take up a job in respective counties). People with low qualifications (up to ISCED 3) represent $16 \%$ of the unemployed with above secondary education. Education and experience are key elements influencing the duration of the process of job seeking. According to the report [58], the average period of unemployment depended on education. With higher education it was approx. 10.5 months; for women with basic 
vocational education, 15 months; for men 12.4 months. People with lower secondary education and below were in the worst situation - the average period of job seeking for women was 15.4 months, and for men, 13.0 months. The share of the professionally inactive with no occupation (i.e., in the most difficult situation) was approx. 19\%. The ranking of deficit and surplus occupations in the Małopolskie province in 2014 [54,59] shows that the largest occupational group of the unemployed was industrial workers and craftsmen. Personal services and sales workers ranked second, and people with no occupation was the third largest groups (due to the lack of qualifications and experience it is most difficult for them to enter the labor market).

In the case of the Krakow Metropolitan Area (KMA), the number of the unemployed is over 39,000 [55], including 28,400 people aged 30+. The county unemployment rate was: from $6.5 \%$ (Krakow county) to $8.8 \%$ (Proszowice and Miechów county), 4.6\% for the City of Krakow, including over 15,700 people $30+$. In the rest of the KMA, a total of 12,700 were registered as unemployed, including approx. 13,000 people $50+$. The $50+$ professional activity rate was over $34 \%$ [56,57]. The average age of the unemployed is growing, unemployment for people aged $50+$ is increasing, but the professional activity of the $50+$ inactive is also increasing dynamically. Among the registered unemployed, over $68 \%$ in the KMA area, i.e., 12,900, are aged 30+, in the City of Krakow the percentage is the lowest within the KMA (60\%), and the highest percentage is observed in the Proszowice county-90\%. According to the NSP 2011 [58], the largest number of people with disabilities lives in Krakow $(107,000)$, over 80,000 in other counties belonging to the KMA.

Comparing the above with the place of residence factor (especially in rural areas) indicates an additional deterioration of the indexes and the accumulation of barriers causing cross discrimination. Within TS, the unemployed from rural areas (except the City of Tarnow) constitute over $80 \%$. Moreover, in rural areas, people with disabilities face more barriers, e.g., in terms of transport or access to forms of support, hence job-seeking activity is lower. In rural areas, $75 \%$ of residents own a computer (the national average is approx. $80 \%$ ), and a greater percentage of people are at risk of digital exclusion (e.g., the use of public e-services accounts for 10\%, compared to $29 \%$ in Małopolska and the national average of $26 \%$ ).

One of the specific objectives of the program was to integrate and activate communities which are particularly at risk of exclusion. The program will help to include all target groups in the process, increasing their mobility and eliminating barriers to digital or transport exclusion, along with the resulting isolation.

\subsection{Methodological Assumptions}

The "Dobry czas na biznes" program was implemented under the Regional Operational Program of the Małopolskie province for 2014-2020, Sub-measure 8.3.1. Support for the new business, co-financed by the European Social Fund (Figure 1) by the MARD. The program targeted residents of TS and KMA (Figure 2) including districts: Bocheński, Krakowski, Miechowski, Myślenicki, Proszowicki, Wielicki and the city of Krakow, who applied for funding to start a business in the years 2015-2016. The KMA is a peculiar functional region. It includes a large city, i.e., Krakow, together with the adjacent communes, interlinked with it by various relationships. The area of the City of Krakow, along with the Krakow county and the neighboring counties, meets the general national requirements for a metropolitan area [60]. 


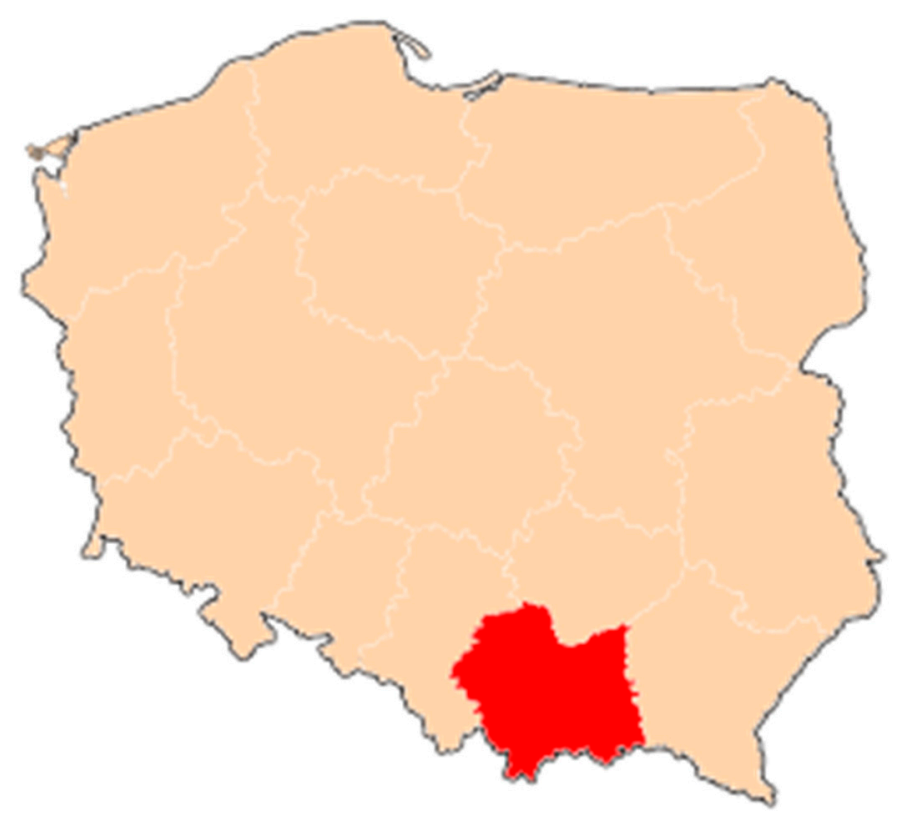

Figure 1. Location of the Małopolskie province on the map of the Republic of Poland. Source: Polska podział administracyjny malopolskie.svg.

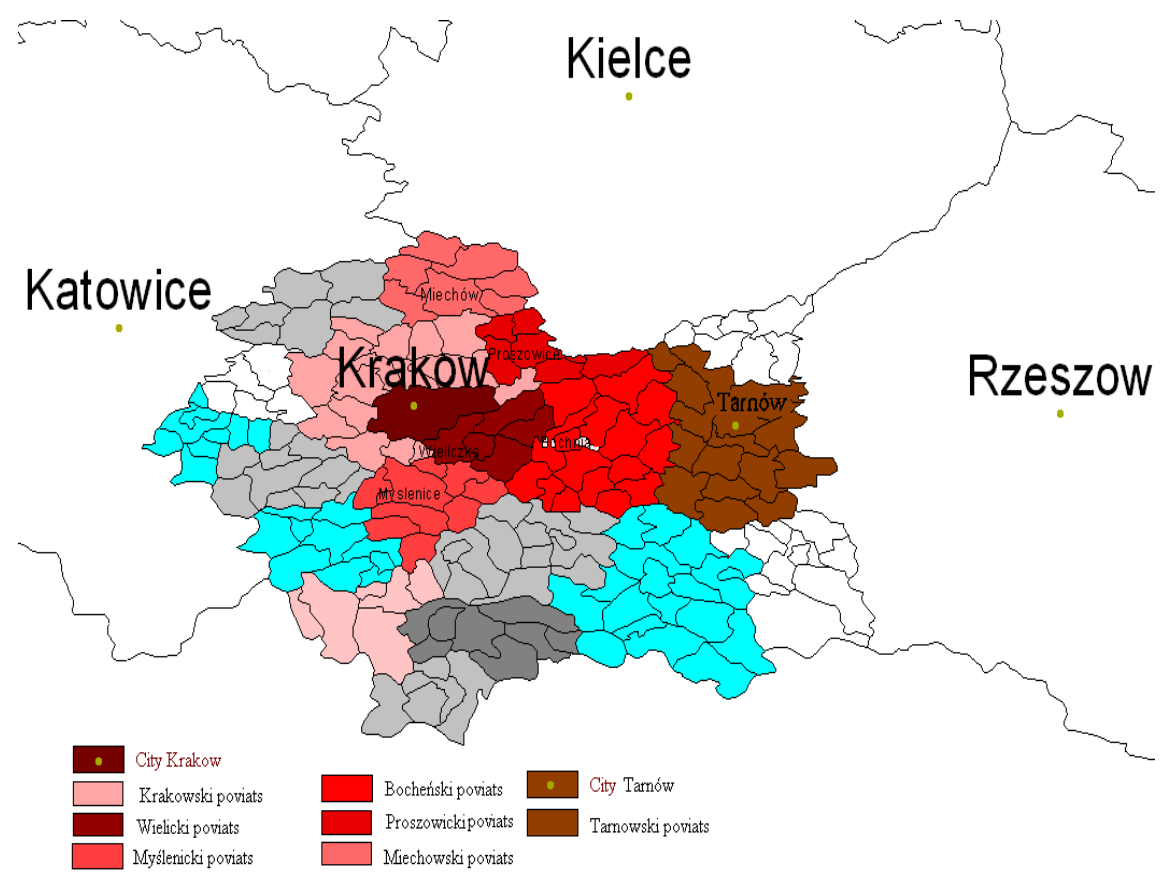

Figure 2. Map of the Małopolskie province with indication of the surveyed area. Source: own study.

The project included a path of support consisting of:

Part I: business start-up training and/or consultancy for all project participants;

Part II:

(a) granting financial support (a subsidy) for new businesses, up to six times the average remuneration, as stated in art. 2, par. 1, p. 28 [61], in force on the date of granting the support, i.e., the date of signing the new business financing subsidy contract,

(b) support and development of new business run by project participants in the initial period (up to 12 months) in the form of advisory services and training support. 
The project was dedicated to the unemployed and professionally inactive aged 30 and over, who were interested in starting a business (excluding persons registered in the Central Register and Information on Business, the National Court Register, or running a business based on separate provisions within the last 12 months preceding the day of joining the project), and who belonged to at least one of the groups: long-term unemployed, people with disabilities, people with low qualifications, women. The data provided by the MARD show that a total of 1819 candidates applied for the funding (1229 from the KMA and 590 from TS), of which 1416 were qualified for the project (934 from KMA and 482 from TS). The program's description was also analyzed for data characterizing employment levels, along with the official unemployment for 2014 (the project's launch) in the Małopolskie province [62,63]. The project was joined by persons registered as unemployed (1.36\%); $1.02 \%$ of them were qualified for the project and $0.85 \%$ qualified for funding.

Based on the previous experience of the authors who acted as experts in such projects, the following research hypotheses were made in the project.

Hypothesis 1 (H1). The number and structure of potential program beneficiaries in the analyzed regions is diversified. Under this hypothesis, three additional sub-hypotheses were introduced.

Hypothesis 1a (H1a). The age structure of project participants is different for each region.

Hypothesis $1 \mathbf{b} \mathbf{~ ( H 1 b ) . ~ T h e ~ g e n d e r ~ s t r u c t u r e ~ o f ~ t h e ~ p r o j e c t ~ p a r t i c i p a n t s ~ i s ~ d i f f e r e n t ~ f o r ~ t h e ~ a n a l y z e d ~ r e g i o n s . ~}$

Hypothesis 1c (H1c). The structure of activity in individual regions.

Further hypotheses related to the structure of the applicants are as follows:

Hypothesis 2 (H2). Younger people are more likely to be interested in projects dedicated to starting a business.

Hypothesis 3 (H3). Women are relatively more often beneficiaries of such programs than men.

Hypothesis 4 (H4). Persons with a shorter professional inactivity period constitute a higher percentage of applicants.

With regard to the effectiveness of applying for the program, the main hypothesis was proposed as follows:

Hypothesis 5 (H5). The effectiveness of obtaining funding under such programs depends on the applicant's age, gender and professional activity. In particular, under this hypothesis, the following sub-hypotheses are proposed:

Hypothesis 5a (H5a). It is relatively easier for younger people to obtain funding in this type of project

Hypothesis $\mathbf{5 b} \mathbf{( H 5 b )}$. Female applicants have a better chance of being accepted into the project;

Hypothesis $\mathbf{5 c} \mathbf{( H 5 c ) . ~ P e o p l e ~ w i t h ~ a ~ s h o r t e r ~ u n e m p l o y e d ~ p e r i o d ~ a r e ~ m o r e ~ l i k e l y ~ t o ~ r e c e i v e ~ f u n d i n g ~ u n d e r ~ t h e ~}$ "Czas na dobry start" project. These hypotheses will be verified based not only on the structure indexes for individual variables, but also on statistical tests, conducted to verify the significance of the existing differentiation.

The statistical analysis is based not only on the presentation of relevant data in a tabular form, but also on the use of appropriate statistical tests. They allow verifying whether the indicated differentiation is statistically significant. These tests also allow verifying the hypotheses set out in the Introduction, i.e., regarding the differentiation of structures in the studied subgroups. For this purpose, an independence test (Pearson's) chi-quadrant was used [54,64]. This test is used to examine the relationship between two nominal (categorical) variables. It is based on comparing observed values (i.e., those obtained in 
the study) with expected values (i.e., those assumed by the test if there is no relationship between the variables). If the difference between the observed and expected values is (statistically) significant, it can be said that there is a relation between one variable and another.

In the part discussing the analysis of effectiveness, in order to verify the indicated differences in the designated structure indexes, an equality test for both two structure indexes and for a larger number of them was used. The proportion test is a parametric test that verifies the hypotheses on the value of proportions in the general population, or compares the value of proportions in several populations based on the known value of this proportion in a random sample (or two or several samples) taken from the population [65].

All the assumptions required for the described tests were fulfilled in the said analyses. The hypotheses were verified with a $5 \%$ significance level $[66,67]$.

\section{Results and Discussion}

\subsection{Analysis of the Participant Structure of the "Dobry Czas na Biznes" Program}

The study of the program participant structure may indicate the target group with the greatest interest in self-employment and help to better prepare the next editions of the program, both at the regional and national level. This is of particular importance for the programming of the spending of public funds (including EU structural funds) allocated to the promotion of entrepreneurship and self-employment.

The analysis of the program participant structure focused mainly on comparing the two areas in which the program was carried out. In particular, the authors compared the age, gender and labor market status of people applying for the program. The analysis provided not only statistical data on the size of the respective groups, but also verification of the statistically significant differences. Table 1 presents the age structure of the program applicants, broken down by their area of residence. The obtained data on age were aggregated data, and the age ranges were indicated by the program organizer based on the guidelines for the operational programs co-financed from structural funds [55].

The analysis of the results presented in Table 2 allows to form a hypothesis that the age distribution of the program participants differs among the presented areas. In particular, significant percentage differences occur in the lowest and highest age groups. More than half of the participants from the KMA are aged 30 to 39 , while only $2.4 \%$ are people over 65 . In the case of TS, people aged 30-39 constitute a smaller group, i.e., just over $42 \%$ of all applicants. On the other hand, every tenth resident of the region was over 65, which is a much higher age average than in the Krakow area. In order to verify whether the said structure difference for both regions is statistically significant, an independence test was performed based on chi-square statistics. The test yielded the statistical value $\chi^{2}=59.221$, based on which the test probability ( $p$-value) was determined, which turned out to be below 0.001 . Thus, the test results clearly indicate a significant diversity in the age structure of program participants in the analyzed areas. In an attempt to explain, it should be noted that TS, which covers the following counties: Dabrowski, Brzeski and Tarnowski (except for the City of Tarnow) are agricultural areas with organic food production traditions [56-61]. It can be concluded that the beneficiaries of the "Dobry Czas na Biznes" program, coming from regions strongly associated with agriculture, decide to change their labor market status and move away from agricultural activities. This part of the analysis confirmed the hypothesis H1a regarding different age structure of program beneficiaries in particular regions. Moreover, the results of Table 2 clearly demonstrate that younger people are more interested in this type of projects, so hypothesis $\mathrm{H} 2$ was confirmed. 
Table 2. Age structure of applicants for financial support.

\begin{tabular}{ccccccc}
\hline \multirow{2}{*}{ Age Range } & \multicolumn{2}{c}{ Krakow Metropolitan Area } & \multicolumn{2}{c}{ Tarnow Subregion } & \multicolumn{2}{c}{ TOTAL } \\
\cline { 2 - 7 } & $\mathbf{N}$ & $\mathbf{\%}$ & $\mathbf{N}$ & $\mathbf{\%}$ & $\mathbf{N}$ & $\mathbf{\%}$ \\
\hline $30-39$ & 683 & 52.6 & 249 & 42.2 & 932 & 49.3 \\
$40-49$ & 317 & 24.4 & 147 & 24.9 & 464 & 24.6 \\
$50-64$ & 268 & 20.6 & 135 & 22.9 & 403 & 21.3 \\
Over 65 & 31 & 2.4 & 59 & 10.0 & 60 & 4.8 \\
TOTAL & 1299 & 68.8 & 590 & 31.2 & 1889 & 100 \\
\hline \multicolumn{7}{c}{ Source: own study. }
\end{tabular}

Another subject of analysis was the gender structure of the project participants. Its results are presented in Table 3.

Table 3. Gender structure of applicants for financial support.

\begin{tabular}{ccccccc}
\hline \multirow{2}{*}{ Gender } & \multicolumn{2}{c}{ Krakow Metropolitan Area } & \multicolumn{2}{c}{ Tarnow Subregion } & \multicolumn{2}{c}{ TOTAL } \\
\cline { 2 - 7 } & $\mathbf{N}$ & $\mathbf{\%}$ & $\mathbf{N}$ & $\mathbf{\%}$ & $\mathbf{N}$ & $\mathbf{\%}$ \\
\hline Women & 763 & 58.7 & 301 & 51.0 & 1064 & 56.3 \\
Men & 536 & 41.3 & 289 & 49.0 & 825 & 43.7 \\
TOTAL & 1299 & 68.8 & 590 & 31.2 & 1889 & 100.0 \\
\hline \multicolumn{7}{c}{ Source: own study. }
\end{tabular}

Even a preliminary analysis of the results presented in the table allows a conclusion that the gender structure of the participants in respective regions is differentiated. Although in both groups the majority of the project participants are women, in TS there is no large disproportion in this respect. The gender division of the participants is very similar, i.e., $51 \%$ of women to $49 \%$ of men. For the Krakow region, these differences are greater as women constitute nearly $59 \%$ of the project participants, and men $41 \%$. The results of the independence test confirmed the significance of the relationship between the rows and columns ( $p$-value $=0.0017$ ) of Table 2 , which proves the diversified gender structure in the analyzed regions. The KMA subregion is an emancipated area, hence the domination of women in the participant structure. Moreover, Krakow, the province's capital, is a city which attracts students and employees from the neighboring counties. By settling in the metropolis, they influence the structure of the population. Based on the above analysis, it is possible to confirm the validity of the adopted hypothesis $\mathrm{H} 1 \mathrm{~b}$ on gender structure differentiation for the analyzed areas of the Małopolskie province. On the other hand, the results from Table 3 allow a conclusion that the assumed H3 hypothesis, i.e., that women more often participate in such projects, was confirmed, but only for the Krakow subregion.

Yet another analysis compares data for the respective regions in the terms of the participants' labor market status. A collective summary of data in this respect is presented in Table 4.

Table 4. The participants' labor market status structure.

\begin{tabular}{ccccccc}
\hline \multirow{2}{*}{ Labor Market Status } & \multicolumn{2}{c}{ Krakow Metropolitan Area } & \multicolumn{2}{c}{ Tarnow Subregion } & \multicolumn{2}{c}{ TOTAL } \\
\cline { 2 - 6 } & $\mathbf{N}$ & $\mathbf{\%}$ & $\mathbf{N}$ & $\mathbf{\%}$ & $\mathbf{N}$ & $\mathbf{\%}$ \\
\hline Short-term unemployed & 480 & 37.0 & 193 & 32.7 & 673 & 35.6 \\
Long-term unemployed & 333 & 25.6 & 232 & 39.3 & 565 & 29.9 \\
Professionally inactive & 486 & 37.4 & 165 & 28.0 & 651 & 34.5 \\
TOTAL & 1299 & 68.8 & 590 & 31.2 & 1889 & 100 \\
\hline
\end{tabular}

Source: own study. 
The comparison in the table above demonstrates that in the project as a whole (taking both areas into account), short-term unemployed and economically inactive people were prevalent. However, upon analyzing respective regions, differences in the described structure can be noticed. While the results for the KMA are consistent with the overall results, the distribution for TS is slightly different. In this part of the Małopolskie province, the long-term unemployed constitute the largest group of applicants, i.e., over $39 \%$. For comparison, in the Krakow area, only one in four applicants remained unemployed for a long time. To verify whether the indicated differences are statistically significant, an independence test was carried out. The obtained statistical result $\chi^{2}=37.966$ means that the statistical significance was at the adopted level of $5 \%$. Thus, hypothesis H1c related to structural differentiation in terms of economic activity of applicants from particular subregions was confirmed.

Therefore, hypothesis $\mathrm{H} 4$ that people who have been professionally inactive for a shorter period of time are more willing to take part in such projects was not fully proved. As demonstrated, it depends on the specifics and conditions of the subregion.

It seems that the main reason is the higher employment dynamics in the KMA subregion. The people who remain unemployed for a long time are fewer. If someone loses their job, they either do not register or the duration of unemployment is short because there are more job offers. The analysis made it possible to learn more about the project participants and to indicate their structural differences for respective subregions. This information is critical and should be used in formulating assumptions, regulations and guidelines for subsequent program editions. Due to the demonstrated diversity of the target group in the respective regions, it should be decided whether to differentiate the criteria for participation in the project depending on the region.

\subsection{Analysis of the Effectiveness of the Application Process}

In this part of the paper, the focus is on examining whether the respective variables described in the previous paragraph determine the applicant's success in obtaining funding. The results of the research aimed at indicating the personal profile of the applicant with best chances for obtaining funding, based on the analyzed data. The research was based on data describing the percentage of people who obtained funding in the respective groups. The results were presented simultaneously for both KMA and TS.

The first comparison described the proportion of applicants who received financing in the respective regions, taking no additional factors into account. In the KMA subregion, $71.9 \%$ of people applying for funding received it. This result is nearly 10 percentage points lower than for TS, in which $81.7 \%$ of applicants received funding. On the basis of the one-sided structure index tests, it was found that the result obtained for TS is significantly higher. Thus, the chances of obtaining funding in the Krakow area were significantly lower than in TS.

Subsequent analyses were carried out taking into account additional factors such as age, gender and labor market status. Table 5 demonstrates the percentage of applicants in each age group who obtained funding.

Table 5. The effectiveness of applying for a subsidy depending on the age of the applicants.

\begin{tabular}{cccc}
\hline Age Range & $\begin{array}{c}\text { Krakow Metropolitan } \\
\text { Area }\end{array}$ & $\begin{array}{c}\text { Tarnow } \\
\text { Subregion }\end{array}$ & $\begin{array}{c}\text { Results of the Equality Test } \\
\text { of the Structure Index for } \\
\text { Respective Regions }\end{array}$ \\
\hline $30-39$ & $74.8 \%$ & $81.5 \%$ & 0.0163 \\
$40-49$ & $70.7 \%$ & $85.7 \%$ & 0.002 \\
$50-64$ & $66.4 \%$ & $83.7 \%$ & 0.001 \\
Over 65 & $67.7 \%$ & $67.8 \%$ & 0.9923 \\
Results of the equality test of & 0.061 & 0.023 & $\mathrm{x}$ \\
structure indexes for age ranges & & & \\
\hline
\end{tabular}


The list presented in the table can be analyzed in two ways.

The first analysis compares the percentage results for each region, respectively, taking into account the additional factor of age. In the case of the Krakow region, the highest percentage of successful applications (nearly 75\%) was noted in the group aged 30-39. However, the lowest percentage was observed for applicants aged 50-64. In this group, just over $66 \%$ of applicants completed the project successfully. A slightly higher success rate was obtained for applicants over 65 . However, the said differentiation did not prove statistically significant, as evidenced by the results of the equality test for many structure indexes (the test probability is above the adopted significance level of 0.05 ).

When TS is concerned, the highest percentage of successful funding occurred for the 40-49 age group, i.e., almost $86 \%$. Definitely the lowest result was obtained for the oldest participants and it is slightly below $68 \%$. This result differs significantly from the results for the other age groups. In TS, the differentiation in the structure indexes for respective age groups turned out to be statistically significant, as the $p$-value in the equality test of the proportion index is 0.023 .

Based on the abovementioned analyses, it can be concluded that the H5a hypothesis was confirmed but only for the Tarnów subregion.

The second analysis compares the percentages of the listed regions, separately for each age group. Table 5 shows that for each age group the percentage result (related to obtaining a subsidy) is higher for TS than for the KMA. No significant difference was noted only in the age group 65+. For the remaining age groups, this difference ranges from about 6 percentage points for the 30-39 year-olds to almost 17 percentage points for the 50-64 age groups. The test results for the structure index confirm that in three out of four age groups the percentage of participants who obtained a subsidy in TS is significantly higher than in the KMA.

Based on the analysis, it can be concluded that in the Krakow region, the chances of obtaining a subsidy are not significantly influenced by the age of the applicant, while in TS this significance has been observed. In this region, the oldest applicants have a much lesser chance of getting a subsidy than younger people. The second part of the analysis shows that it is much easier to obtain a subsidy in TS than in the KMA, for all age groups except one (the oldest).

The following part of the paper is dedicated to similar research, but aimed at the applicants' gender factor. Table 6 presents information on the percentage of men and women who obtained funding in the respective regions.

Table 6. Effectiveness of applying for a subsidy depending on the gender of applicants.

\begin{tabular}{cccc}
\hline Gender & $\begin{array}{c}\text { Krakow Metropolitan } \\
\text { Area }\end{array}$ & $\begin{array}{c}\text { Tarnow } \\
\text { Subregion }\end{array}$ & $\begin{array}{c}\text { Results of the Equality Test } \\
\text { of the Structure Index for } \\
\text { Respective Regions }\end{array}$ \\
\hline $\begin{array}{c}\text { Women } \\
\text { Men }\end{array}$ & $68.5 \%$ & $78.7 \%$ & 0.005 \\
Results of the equality test of & $76.7 \%$ & $84.8 \%$ & 0.003 \\
structure indexes for age ranges & 0.006 & 0.0277 & $\mathrm{x}$ \\
\hline & Source: own study.
\end{tabular}

Based on the analysis of the gender differentiation index of the obtained financing, we conclude that in each of the regions men received co-financing more often than women. The difference in both regions is approx. 8 percentage points in favor of men. As demonstrated by the tests, these differences are statistically significant. Therefore, based on the analyzed data, it can be concluded that, regardless of the region, it is easier for men to obtain funding under the program.

Based on the previous analysis, it was demonstrated that in TS, the percentage of obtained funding is higher. It turns out that it is spread quite evenly if the applicants' gender is taken into account in the analysis, as well. The percentage of women from TS who obtained funding was over 10 percentage points higher than that of women from the KMA. For men, this difference was approx. 8 percentage points. In both cases, the identified difference turned out to be statistically significant. Please note that 
the conclusions of the above analysis are not consistent with the initial hypothesis H5b. Contrary to predictions, there is a higher percentage of men, and not women, with a positive project outcome, i.e., obtained subsidy. The character of socio-economic conditions in the subregions should also be taken into account in this respect.

The last part of the analysis was related to the study of the impact of employment status on the chances of obtaining a subsidy. Table 7 presents information on the percentage of successful applicants in particular groups.

Table 7. Effectiveness of applying for a subsidy depending on the applicant's labor market status.

\begin{tabular}{cccc}
\hline Labor Market Status & $\begin{array}{c}\text { Krakow Metropolitan } \\
\text { Area }\end{array}$ & $\begin{array}{c}\text { Tarnow } \\
\text { Subregion }\end{array}$ & $\begin{array}{c}\text { Results of the Equality Test } \\
\text { of the Structure Index for } \\
\text { Respective Regions }\end{array}$ \\
\hline Short-term unemployed & $76.9 \%$ & $85.0 \%$ & 0.0164 \\
Long-term unemployed & $69.4 \%$ & $84.9 \%$ & 0.000 \\
$\quad \begin{array}{c}\text { Professionally inactive } \\
\text { Results of the equality test of }\end{array}$ & $68.7 \%$ & $73.3 \%$ & 0.1329 \\
structure indexes for age ranges & 0.0093 & 0.0047 & $\mathrm{x}$ \\
\hline
\end{tabular}

Source: own study.

Based on the data collected in Table 7, it can be concluded that in both regions there are differences in the structure of the proportion of successful applicants, taking into account their labor market status. In the KMA, the highest percentage of obtaining a subsidy occurs decidedly among the short-term unemployed. On average, 77 out of 100 people in this group obtained funding and this result is approx. 8 percentage points higher than in the other groups. The demonstrated differentiation turned out to be statistically significant as the test probability value is 0.0093 and is below the significance level adopted in the test. In TS, the percentage of successful applicants in both of the unemployed groups is similar and amounts to approximately $85 \%$. In TS, the percentage was lower by over 11 points for the professionally inactive. Based on the test, it was concluded that this difference is statistically significant. Thus, the H5c hypothesis was confirmed by the analysis.

The comparison of the structure index between regions in respective groups is favorable for TS (for each group). However, based on the test, it can be concluded that the difference in the analyzed percentages is significant only for the groups of the unemployed. In the case of the economically inactive, the difference of 4.6 percentage points did not prove statistically significant.

Based on the analyses, the authors ventured to create a profile of the applicant with the best chance of obtaining a subsidy in the program. In the case of KMA, men who are unemployed for a short period of time have the best chance of obtaining a subsidy. In this region, age is not of significant importance, however, the analyses point to younger applicants as more likely to receive a subsidy. In TS, an unemployed man aged 40-49 had the greatest chance of obtaining a subsidy (regardless of the length of the period of unemployment). As mentioned above, the results of the analysis of the effectiveness of the application process did not fully confirm the adopted main hypothesis H5. It was confirmed that it is easier for the short-term professionally inactive to obtain a subsidy, but in terms of age and gender, the assumptions turned out to be incorrect.

\section{Conslusions and Limitations}

The impact of investment subsidies on the promotion of self-employment was evaluated based on the quantitative characteristics of the "Dobry czas na biznes" program implemented by the Małopolska Agencja Rozwoju Regionalnego S.A. (MARR S.A.) It is worth noting that participation in the program requires the unemployed person to take up searching, analyzing and assessing information that appears in the public space. It also requires drawing conclusions regarding one's personal situation resulting from, e.g., their place of residence, mobility, education and experience and other qualifying characteristics for self-employment. 
In summary, it is worth emphasizing that initiatives such as the "Dobry czas na biznes" program are noticeable on the regional market. They improve the situation of the program participants but also of their families, shaping a positive image of work. Participation in the program means not only financing for the planned business activity, but also gaining knowledge and establishing relationships that may in the future help the new business owner develop professionally and better cope with problems and challenges. In rural areas, resources, including labor force, are largely complementary to the resources assembled in the largest development centers and when properly used, can significantly contribute to increasing the region's competitiveness [68-70]. In the analyzed sub-regions, rural economy is not diversified enough, with a poor selection of job offers outside the agricultural sector. It is therefore necessary to support the development of rural areas as part of the structural policy and European funds through activities such as consultancy and training, enabling the transfer of knowledge and skills necessary to start and run a business, as well as subsidies for business development [71-75]. Please note that most of the hypotheses posed by the authors were confirmed. Those that were not confirmed were commented accordingly, followed by proposed explanations of the inconsistencies between the analysis results with the authors' predictions.

The results are of key importance and should be used in formulating assumptions, regulations and guidelines for subsequent program editions. The ongoing discussion on the shape of the budget under the Multiannual Financial Framework 2020-2027 feeds into a discussion within the EU member states on the direction of public interventionism in supporting and promoting entrepreneurship and self-employment. The presented results may provide an important argument for decision-makers in rural regions to define support criteria within individual operational programs.

Due to the demonstrated diversity of the target group in respective regions, it should be decided whether to differentiate the criteria for participation in the project depending on the region.

Among the limitations of the conducted research, the authors indicate the following.

1. Please note that the data used in the study are not widely available to scientists and researchers. Therefore, there are very few similar studies in the literature. As a result, the authors had limited opportunity to compare their results with those of other authors. Moreover, there was no possibility to refer to other studies on the same subject. The results of research available in the literature, related to public intervention programs addressed to family businesses, address the topics of succession, business models and relational capital [76-78]. The subject matter of the authors' research is generically different and thus incomparable.

2. The dynamics of the program participant and program beneficiaries structures are worth further investigation, which the authors have undertaken already.

3. Since only two regions were taken into consideration, it is recommended to expand the geographical scope of the research. To verify whether the results in other regions are comparable, data from other regions must be obtained and analyzed accordingly.

4. The obtained data, although original and of limited availability, were aggregated data. This significantly limits the possibility of conducting statistical analyses.

Author Contributions: Conceptualization, Z.G.-S., M.S.; methodology, M.S., Z.G.-S., A.S.-S.; validation, L.O.S. and M.S. formal analysis, Z.G.-S., L.O.S.; resources, A.S.-S., L.O.S., Z.G.-S.; data curation, M.S.; writing-Original draft preparation, M.S., Z.G.-S., L.O.S.; writing-review and editing, A.S.-S.; visualization, Z.G.-S., M.S., A.S.-S.; supervision, L.O.S. project administration. All authors have read and agreed to the published version of the manuscript.

Funding: Publication financed by the subsidy granted to the Cracow University of Economics. The publication is financed by a subsidy for the Faculty of Management of AGH University for the maintenance and development of research potential.

Conflicts of Interest: The authors declare no conflict of interest. 


\section{References}

1. Ribeiro-Soriano, D.; Urbano, D. Employee-organization relationship in collective entrepreneurship: An overview. J. Organ. Chang. Manag. 2010, 23, 349-359. [CrossRef]

2. Staniewski, M. Postawa Młodzieży Wobec Przedsiębiorczości i Nadzieja na Sukces. Sprawa Polskich Studentów; Konferencja SAIMS 2009 “Dyskurs Zarządzania Przedsiębiorstwem w Nowym Tysiącleciu: Wyzwania i Szanse"; RPA: Port Elizabeth, South Africa, 2009.

3. Gottschalk, S.; Greene, F.J.; Müller, B. The impact of habitual entrepreneurial experience on new firm closure outcomes. Small Bus. Econ. 2017, 48, 303. [CrossRef]

4. Kajrunajtys, D.; Szarucki, M. Business Processes Management in an Intelligent Organization on the Example of WSEI. In Internet in the Information Society: Computer Systems Architecture and Security; Pikiewicz, P., Rostański, M., Eds.; Academy of Business: Dabrowa Górnicza, Poland, 2013; pp. 19-34.

5. Van Gelderen, M.; Jansen, P. Autonomy as a start-up motive. J. Small Bus. Enterp. Dev. 2006, 13, $23-32$. [CrossRef]

6. Haltiwanger, J.; Jarmin, R.S.; Miranda, J. Who creates jobs? Small versus large versus young. Rev. Econ. Stat. 2013, 95, 347-361. [CrossRef]

7. Skrzek-Lubasińska, M. Instytucje a Konkurencyjność Przedsiębiorstwa; Oficyna Wydawnicza SGH: Warszawa, Poland, 2017.

8. Rey-Martí, A.; Tur Porcar, A.; Mas-Tur, A. Linking female entrepreneurs' motivation to business survival. J. Bus. Res. 2015, 68, 810-814. [CrossRef]

9. Bernat, T.; Korpysa, J.; Kunasz, M. Przedsiębiorczość Osób Uczących Się-Raport z Badań; Uniwersytet Szczeciński, Katedra Mikroekonomii: Szczecin, Poland, 2008.

10. Carsrud, A.; Brännback, M. Entrepreneurial motivations: What do we still need to know? J. Small Bus. Manag. 2011, 49, 9-26. [CrossRef]

11. Wright, M.; Stigliani, I. Entrepreneurship and growth. Int. Small Bus. J. 2013, 31, 3-22. [CrossRef]

12. Armengot, C.R.; Parellada, F.S.; Carbonell, J.R. The immigrant entrepreneur in the international change: A managerial analysis according to demographic profile. J. Organ. Chang. Manag. 2010, 23, 377-395. [CrossRef]

13. Hessels, J.; van Gelderen, M.; Thurik, R. Entrepreneurial aspirations, motivations, and their drivers. Small Bus. Econ. 2008, 31, 323-339. [CrossRef]

14. Estay, C.; Durrieu, F.; Akhter, M. Entrepreneurship: From motivation to start-up. J. Int. Entrep. 2013, 11, 243-267. [CrossRef]

15. Rajan, R.G.; Zingales, L. Financial Dependence and Growth. Am. Econ. Rev. 1998, 88, 559-586.

16. Mama, H.B. Nonlinear capital market payoffs to science-led innovation. Res. Policy 2018, 47, $1084-1095$. [CrossRef]

17. Ortiz-Villajos, J.M.; Sotocka, S. Innovation and business survival: A long-term approach. Res. Policy 2018, 4, 1418-1436. [CrossRef]

18. Basu, A.; Parker, S.C. Family Finance and New Business Start-ups. Oxf. Bull. Econ. Stat. 2001, 63, 333-358. [CrossRef]

19. Bates, T. Financing small business creation: The case of Chinese and Korean immigrant entrepreneurs. J. Bus. Ventur. 1997, 12, 109-124. [CrossRef]

20. Bădulescu, A. Start-Up Financing Sources: Does Gender Matter? Some Evidence for Eu and Romania. Ann. Univ. Oradea Econ. Sci. Ser. 2011, 1, 207-213.

21. Henderson, R. Underinvestment and incompetence as responses to radical innovation: Evidence from the photolithographic alignment equipment industry. Rand J. Econ. 1993, 24, 248-270. [CrossRef]

22. Gródek-Szostak, Z.; Szelagg-Sikora, A.; Sikora, J.; Korenko, M. Prerequisites for the cooperation between enterprises and business supportinstitutions for technological development. In Proceedings of the 16th International Conference, Tomaszowice, Poland, 19-20 June 2017; Volume 16, pp. 427-439.

23. Henkel, J.; Rønde, T.; Wagner, M. And the winner is-Acquired. Entrepreneurship as a contest yielding radical innovations. Res. Policy 2015, 44, 295-310. [CrossRef]

24. Carpenter, R.E.; Petersen, B.C. Capital market imperfections, high-tech investment, and new equity financing. Econ. J. 2002, 112, F54-F72. [CrossRef] 
25. Acs, Z.J.; Audretsch, D.B. Innovation in large and small firms: An empirical analysis. Am. Econ. Rev. 1988, 78, 678-690.

26. Anton, J.J.; Yao, D.A. The sale of ideas: Strategic disclosure, property rights, and contracting. Rev. Econ. Stud. 2002, 69, 513-531. [CrossRef]

27. Hellmann, T.; Perotti, E. The circulation of ideas in firms and markets. Manag. Sci. 2011, 57, $1813-1826$. [CrossRef]

28. David, P.A.; Hall, B.H.; Toole, A.A. Is public R\&D a complement or substitute for private R\&D? A review of the econometric evidence. Res. Policy 2000, 29, 497-529.

29. Cerulli, G. Modelling and measuring the effect of public subsidies on business R\&D: A critical review of the econometric literature. Econ. Rec. 2010, 86, 421-449.

30. Zúñiga-Vicente, J.; Alonso-Borrego, C.; Forcadell, F.J.; Galán, J.I. Assessing the effect of public subsidies on firm R\&D investment: A survey. J. Econ. Surv. 2014, 28, 36-67.

31. Becker, B. Public R\&D policies and private R\&D investment: A survey of the empirical evidence. J. Econ. Surv. 2015, 29, 917-942.

32. Lerner, J. The government as venture capitalist: The long-run effects of the SBIR program. J. Bus. 1999, 72, 285-318. [CrossRef]

33. Howell, S.T. Financing innovation: Evidence from R\&D grants. Am. Econ. Rev. 2017, 107, 1136-1164.

34. Söderblom, A.; Samuelsson, M.; Wiklund, J.; Sandberg, R. Inside the black box of outcome additionality: Effects of early-stage government subsidies on resource accumulation and new venture performance. Res. Policy 2015, 44, 1501-1512. [CrossRef]

35. Colombo, M.G.; Grilli, L.; Murtinu, S. R\&D subsidies and the performance of high-tech start-ups. Econ. Lett. 2011, 112, 97-99.

36. Grilli, L.; Murtinu, S. Government, venture capital and the growth of European high-tech entrepreneurial firms. Res. Policy 2014, 43, 1523-1543. [CrossRef]

37. Colombo, M.G.; Croce, A.; Guerini, M. The effect of public subsidies on firms' investment-cash flow sensitivity: Transient or persistent? Res. Policy 2013, 42, 1605-1623. [CrossRef]

38. Cantner, U.; Kösters, S. Public R\&D support for newly founded firms: Effects on patent activity and employment growth. J. Innov. Econ. Manag. 2015, 1, 7-37.

39. Conti, A. Entrepreneurial finance and the effects of restrictions on government R\&D subsidies. Org. Sci. 2018, 29, 134-153.

40. Almeida, R.; Galasso, E. Jump-Starting Self-Employment? Evidence Among Welfare Participants in Argentina. Discuss. Pap. 2007, 2902. [CrossRef]

41. Rodriguez-Planas, N. Channels through Which Public Employment Services and Small-Business Assistance Programs Work. Oxf. Bull. Econ. Stat. 2010, 72, 458-485. [CrossRef]

42. O'Leary, C.J. Promoting Self Employment among the Unemployed in Hungary and Poland. In Upjohn Institute Working Papers; Upjohn Institute for Employment Research: Kalamazoo, MI, USA, 1999. [CrossRef]

43. Carling, K.; Gustafson, L. Self-Employment Grants vs. Subsidized Employment: Is There a Difference in the Re-Unemployment Risk; IFAU-Institute for Labour Market Policy Evaluation: Uppsala, Sweden, 1999; Available online: https://www.econstor.eu/bitstream/10419/82164/1/wp99-06.pdf (accessed on 19 November 2020).

44. Cueto, B.; Mato, J. An Analysis of Self-Employment Subsidies with Duration Models. Appl. Econ. 2006, 38, 23-32. [CrossRef]

45. Perry, G. Are Business Start-Up Subsidies Effective for the Unemployed: Evaluation of Enterprise Allowance; Working Paper; Auckland University of Technology: Auckland, New Zealand, 2006.

46. Meager, M.; Bates, P.; Cowling, M. An Evaluation of Business Start-Up Support for Young People. Natl. Inst. Econ. Rev. 2003, 186, 59-72. [CrossRef]

47. Kelly, R.; Lewis, P.; Mulvey, C.; Dalzell, B. A Study to Better Assess the Outcomes in the New Enterprise Incentive Scheme: Report Prepared for the Department of Employment and Work Place Relations; University of Western Australia, the Centre for Labour Market Research: Perth, Australia, 2002.

48. Kubera, P. Ocena skuteczności i efektywności instrumentów pomocy publicznej. Studia Ekon. 2013, 168, 96-109. 
49. Bachnik, K. Wykorzystanie funduszy unijnych a stymulowanie innowacyjności przedsiębiorstw. In Wptyw Interwencji z Funduszy Unijnych na Funkcjonowanie Przedsiębiorstw i Ich Konkurencyjność; Karpińska-Mizielińska, W., Smuga, T., Eds.; CeDeWu: Warsaw, Poland, 2015; pp. 115-138.

50. Jegorow, D. Uruchamianie działalności gospodarczej przy wsparciu dotacji a rozwój przedsiębiorczości. Eduk. Ekon. I Menedżerów 2016, 3, 59-74.

51. Chang, H. Rzeczy, Których Nie Mówia ci o Kapitalizmie; Wydawnictwo Krytyki Politycznej: Warsaw, Poland, 2013.

52. Staniewski, M.W.; Szopiński, T.; Awruk, K. Setting up a business and funding sources. J. Bus. Res. 2016, 69, 2108-2112. [CrossRef]

53. Gołąbocka-Auleytner, K. Możliwości pozyskiwania i wykorzystania w przedsiębiorstwach środków finansowych z funduszy strukturalnych Unii Europejskiej. In Wybrane Problemy Zarzadzania w Gospodarce Opartej Na Wiedzy—Przedsiębiorczość i Zachowania Innowacyjne; Makowiec, M., Mikuła, B., Pietruszka-Ortyl, A., Eds.; Department of Organizational Behaviors, Cracow University of Economics: Krakow, Poland, 2018; pp. 67-82.

54. Główny Urząd Statystyczny (GUS). Badanie Aktywności Ekonomicznej Ludności 2014; GUS: Warszwa, Poland, 2014. Available online: https://stat.gov.pl/download/gfx/portalinformacyjny/pl/defaultaktualnosci/5475/4/15/ 1/aktywnosc_ekonomiczna_iv_kw_2014.pdf (accessed on 23 July 2020).

55. Główny Urząd Statystyczny (GUS). Badanie Aktywności Ekonomicznej Ludności 2015; GUS: Warszwa, Poland, 2015. Available online: aktywnosc_ekonomiczna_ludnosci_polski_ikw_2015.pdf (accessed on 23 July 2020).

56. Raport Otwarcia Koalicji Cyfrowego Włączenia Generacji 50+ “Dojrz@łość w sieci”. Available online: http: //www.zarz.agh.edu.pl/wkowalik/publikacje/Dojrzalosc_w_Sieci-Raport.pdf (accessed on 24 July 2020).

57. Wojewódzki Program Dotyczacy Wyrównywania Szans osób Niepełnosprawnych i Przeciwdziałania ich Wykluczeniu Społecznemu oraz Pomocy w Realizacji Zadań na rzecz Zatrudniania osób Niepetnosprawnych w Województwie Małopolskim na Lata 2014-2020; Urząd Marszałkowski Województwa Małopolskiego Departament Zdrowia i Polityki Społecznej: Kraków, Poladn, 2014.

58. GUS. Narodowy Spis Powszechny Ludności i Mieszkań 2011. Available online: https://stat.gov.pl/cps/rde/ xbcr/gus/lud_raport_z_wynikow_NSP2011.pdf (accessed on 24 July 2020).

59. Ranking Zawodów Deficytowych i Nadwyżkowych w Województwie Małopolskim 2015. Available online: https://wupkrakow.praca.gov.pl/documents/67976/2615714/Ranking\%20zawod\%C3\%B3w\%20deficytowych\% 20i\%20nadwy\%C5\%BCkowych\%20w\%202014\%20roku/b2996131--6849--4a19--9ffb-c295f4e0597a?t= 1513341879127 (accessed on 24 July 2020).

60. Ustawa z Dnia 11 Lipca 2014 r. o Zasadach Realizacji Programów w Zakresie Polityki Spójności Finansowanych w Perspektywie Finansowej 2014-2020. Dz.U. 2014 Poz. 1146. Available online: https://www.funduszeeuropejskie. gov.pl/media/43637/D20141146Lj.pdf (accessed on 24 July 2020).

61. Uchwała Nr XV/174/03 Sejmiku Województwa Małopolskiego z dnia 22 grudnia 2003 r. Plan Zagospodarowania Przestrzennego Województwa Małopolskiego. Available online: http://edziennik.malopolska.uw.gov.pl/WDU_ K/2018/3215/akt.pdf (accessed on 24 July 2020).

62. Ustawa z Dnia 20 Kwietnia 2004 r. o Promocji Zatrudnienia i Instytucjach Rynku Pracy, Dz. U. 2004 Nr 99 poz. 1001. Available online: http://isap.sejm.gov.pl/isap.nsf/DocDetails.xsp?id=WDU20040991001 (accessed on 18 July 2020).

63. MORP, Pracodawca-Rynek—Pracownik. Raport z Badania Zapotrzebowania Na Pracowników Wśród Małopolskich Pracodawców 2014. Available online: https://www.obserwatorium.malopolska.pl/wp-content/ uploads/2016/05/Raport_pracodawca-rynek-pracownik_2014.pdf (accessed on 20 November 2020).

64. Greenwood, P.E.; Nikulin, M.S. A Guide Testem Chi-Kwadrat; Wiley: Nowy Jork, NY, USA, 1996.

65. Fisher, R.A.; Yates, F. Statistical Tables for Biological, Agricultural and Medical Research; Oliver and Boyd: Edinburgh, UK, 1963.

66. Gurgul, H.; Suder, M. Impact of ATM location on its profitability in Malopolskie and Podkarpackie provinces. Manag. Econ. 2018, 19, 49-73.

67. Hsu, D.H. Experienced entrepreneurial founders, organizational capital, and venture capital funding. Res. Policy 2007, 36, 722-741. [CrossRef]

68. Myers, S.C.; Majluf, N.S. Corporate financing and investment decisions when firms have information that investors do not have. J. Financ. Econ. 1984, 13, 187-221. [CrossRef]

69. Nilsen, Ø.A.; Raknerud, A.; Iancu, D.C. Public R\&D Support and Firms' Performance a Panel Data Study. Cesifo Work. Pap. 2018, 7131. [CrossRef] 
70. Schneider, C.; Veugelers, R. On young highly innovative companies: Why they matter and how (not) to policy support them. Ind. Corp. Chang. 2010, 19, 969-1007. [CrossRef]

71. Smith, J.A.; Todd, P.E. Does matching overcome LaLonde's critique of nonexperimental estimators? J. Econom. 2005, 125, 305-353. [CrossRef]

72. Storey, D.J.; Tether, B.S. New technology-based firms in the European Union: An introduction. Res. Policy 1998, 26, 933-946. [CrossRef]

73. Stucki, T. How the founders' general and specific human capital drives export activities of start-ups. Res. Policy 2016, 45, 1014-1030. [CrossRef]

74. Williamson, O.E. Comparative economic organization: The analysis of discrete structural alternatives. Adm. Sci. Q. 1991, 36, 269-296. [CrossRef]

75. Gródek-Szostak, Z.; Kajrunajtys, D. Job—Related Adult Education Using Adaptive Software. Available online: https://www.researchgate.net/profile/Zofia_Grodek-Szostak/publication/339916485_JOB-RELATED_ADULT_ EDUCATION_USING_ADAPTIVE_SOFTWARE/links/5e6bfdc5299bf12e23c33f4b/JOB-RELATED-ADULTEDUCATION-USING-ADAPTIVE-SOFTWARE.pdf (accessed on 20 November 2020).

76. Basco, R. Family business and regional development-A theoretical model of regional familiness. J. Fam. Bus. Strategy 2015, 6, 259-271. [CrossRef]

77. Fletcher, D.; De Massis, A.; Nordqvist, M. Qualitative research practices and family business scholarship: A review and future research agenda. J. Fam. Bus. Strategy 2016, 7, 8-25. [CrossRef]

78. Debicki, B.J.; Ramírez-Solís, E.R.; Baños-Monroy, V.I.; Gutiérrez-Patrón, L.M. The impact of strategic focus on relational capital: A comparative study of family and non-family firms. J. Bus. Res. 2020, in press, corrected proof. [CrossRef]

Publisher's Note: MDPI stays neutral with regard to jurisdictional claims in published maps and institutional affiliations. 